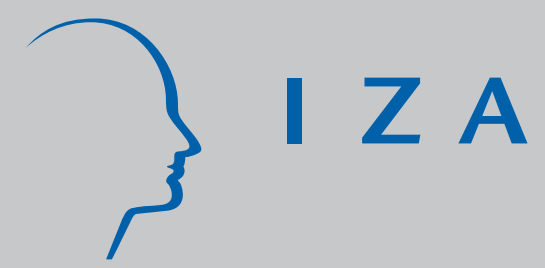

IZA DP No. 7272

Investment Crowding-Out and Labor Market Effects of Financialization in the U.S.

Ignacio González

Hector Sala

March 2013

Forschungsinstitut zur Zukunft der Arbeit Institute for the Study of Labor 


\title{
Investment Crowding-Out and Labor Market Effects of Financialization in the U.S.
}

\author{
Ignacio González \\ European University Institute \\ Hector Sala \\ Universitat Autònoma de Barcelona \\ and IZA
}

Discussion Paper No. 7272

March 2013

IZA

P.O. Box 7240

53072 Bonn

Germany

Phone: +49-228-3894-0

Fax: +49-228-3894-180

E-mail: iza@iza.org

\begin{abstract}
Any opinions expressed here are those of the author(s) and not those of IZA. Research published in this series may include views on policy, but the institute itself takes no institutional policy positions. The IZA research network is committed to the IZA Guiding Principles of Research Integrity.

The Institute for the Study of Labor (IZA) in Bonn is a local and virtual international research center and a place of communication between science, politics and business. IZA is an independent nonprofit organization supported by Deutsche Post Foundation. The center is associated with the University of Bonn and offers a stimulating research environment through its international network, workshops and conferences, data service, project support, research visits and doctoral program. IZA engages in (i) original and internationally competitive research in all fields of labor economics, (ii) development of policy concepts, and (iii) dissemination of research results and concepts to the interested public.
\end{abstract}

IZA Discussion Papers often represent preliminary work and are circulated to encourage discussion. Citation of such a paper should account for its provisional character. A revised version may be available directly from the author. 


\section{ABSTRACT \\ Investment Crowding-Out and Labor Market Effects of Financialization in the U.S.}

This paper studies the impact of financialization on unemployment in the U.S. We estimate a dynamic multi-equation macro labor model including labor demand, labor supply, wagesetting and capital accumulation equations. Financialization appears as a key determinant of capital accumulation which, in turn, is the transmission channel towards its unemployment effects. We conduct a series of counterfactual simulations where we quantify the macroeconomic consequences of the recent swings experienced by the financialization process. We find that it has had relevant unemployment effects in all periods considered, even in those where financial payments were not the main driver of capital accumulation. We also identify a structural change in the financialization process in the early 1980s, and find that it has caused U.S. unemployment to systematically fluctuate around 2 percentage points above what it would otherwise have done. We call for a reappraisal of the way financial markets work, and stress the vital need of preventing financial devices that result in productive investment crowding-out.

JEL Classification: D2, E22, E24, G2

Keywords: financialization, capital accumulation, unemployment, chain reaction theory

Corresponding author:

Hector Sala

Departament d'Economia Aplicada

Universitat Autònoma de Barcelona

Edifici B

08193 Bellaterra

Spain

E-mail: hector.sala@uab.es

\footnotetext{
* We are thankful to two anonymous referees whose comments and suggestions have greatly contributed to improve this article. Ignacio González is grateful to "laCaixa" Foundation for a postgraduate grant under which this research could be conducted. Hector Sala gratefully acknowledges financial support from the Spanish Ministry of Economy and Competitiveness through grant ECO2012-13081.
} 


\section{Introduction}

Economic and financial activities have experienced a long period of deregulation dating back to the early 1980s. Within this context, a salient feature has been the financialization process of the non-financial corporate sector. There has been much concern on the causes that have recently led the world economy to the Great Recession and the progressive financialization of real activities has systematically been at the core of the analysis. Less attention, however, has been paid to the real consequences of this phenomenon, for example in terms of economic growth or labor outcomes.

In this study we discuss, at a macro level, the impact of financialization on U.S. unemployment through its effect on capital accumulation. In particular we aim at answering the following question: How much unemployment explained by variations in capital accumulation is the result of the financialization process of the non-financial corporate sector?

Figure 1. Financialization, capital accumulation and unemployment in the U.S. b. Capital accumulation vs. financial paym ents b. Capital accumulation vs. the unemployment rate
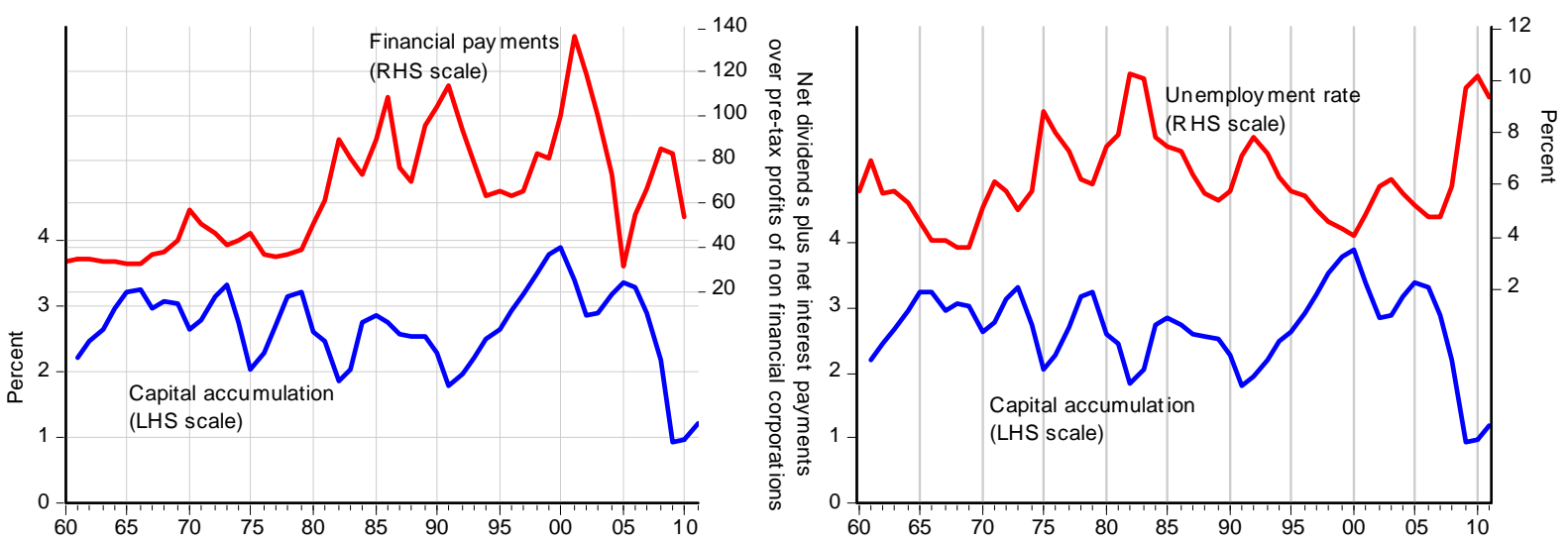

Figure 1 provides some preliminary information on the relationship between these variables. In figure 1a we observe a negative relationship between capital accumulation and financial payments (which is, as we explain later in detail, our selected indicator of the financialization phenomenon). ${ }^{1}$ In general, periods of rapid accumulation of capital coincide with situations of decreasing financial payments, although this is not always the case since both variables might respond positively to common determinants such as technological shocks or other sources of business cycles fluctuations. In turn, figure $1 \mathrm{~b}$

\footnotetext{
${ }^{1}$ Financial payments is the ratio between net dividends plus net interests over total pre-tax profits of non-financial corporations (NFCOs). We focus on NFCOs not only because these firms are directly responsible of the vast majority of gross capital formation and private job creation, but also because it is in this sector where the financialization phenomenon takes place (it is indeed where the shareholders are, although the close link between corporate and non-corporate firms makes it spread to all the economy). Of course, the financialization process is also reflected in the households' behavior (for example, through their growing indebtedness), but this side of the process lies beyond the scope of our analysis (confined to supply-side issues).
} 
displays a neat negative relationship between capital accumulation and the unemployment rate. The two series evolve almost as a mirror image and readily question the conventional wisdom according to which the evolution of unemployment is independent of growing variables such as capital stock or productivity (Layard et al. 1991).

Some recent literature has already documented the negative effects of the increased financialization on real investment (for example, Stockhammer 2004a, Van Treeck 2008, and Orhangazi 2008). Our contribution seeks to go beyond the accredited financializationcapital accumulation negative relationship, and aims at quantifying the impact of financialization on unemployment. Nevertheless, since the transmission channel from the financialization process to its labor outcome is capital accumulation (by way, mainly, of its employment impact), this paper is related to that literature.

Our methodological approach, however, differs in various respects, both to this related literature and to the mainstream one regarding macro-labor studies. First of all we attach to the so called chain reaction theory (CRT henceforth) and conceive the labor market as not driven by an equilibrium measure of unemployment towards which the labor market unambiguously converges. ${ }^{2}$ This implies that a concept such as the Natural Rate of Unemployment is not central to our labor market analysis. Second, instead of focusing on the estimation of a reduced form unemployment rate equation, we evaluate the contribution of financialization to unemployment using a dynamic multi-equation labor market system (with estimated labor demand, labor force, and wage equations) that incorporates a capital accumulation equation. Third, we conduct counterfactual simulations to assess the macroeconomic effects of the financialization process for capital accumulation and the performance of the labor market. The endogenization of the capital factor in a CRT context is one of the contributions of this study. The other one is the provision of new empirical evidence on the unemployment effects that the financialization process is having by crowding out productive investment.

The counterfactual simulations exploit the information given by impulse response functions (hereafter IRFs) computed on the estimated system of equations. The fact that IRFs are a focal point in the analysis of its models is one of the salient characteristics of the CRT methodology. In contrast to the (S)VAR methodology, CRT models define the impulses (shocks) as changes in the exogenous variables, whereas in (S)VARs, the impulses (one-off shocks) relate to the error term of a specific equation in the (S)VAR model. Defining the shocks as changes in exogenous variables confer CRT models two advantages over (S)VAR models (Karanassou and Sala 2010b). First, it gives rise to a "contributions" measure, which shows how unemployment (or any endogenous variable in the CRT model) responds to the actual changes in an exogenous variable over a sample interval. Second, since changes in the exogenous variables are associated to policy changes, CRT

\footnotetext{
${ }^{2}$ See Karanassou et al. (2010) for a recent and comprehensive overview of the CRT approach.
} 
models allow for the identification of policy effects. ${ }^{3}$ This is precisely what we do through the counterfactual simulations: we evaluate the contribution of financialization shocks (changes in this variable) to unemployment.

The first central finding is that financialization has relevant macroeconomic effects in all periods considered, which vary between 1.5 (in 1997-2001) and 4.9 percentage points of unemployment (in 1991-1997). In 1991-1997, financial payments fell sharply and had a fundamental contribution by preventing any sort of crowding out and letting private investment be fueled. This effect may well be considered one of the driving forces of the roaring nineties in connection with the monetary expansion implemented by the Fed in those years. In 2001-2005, financial payments also fell and account for 2.5 percentage points decrease in the unemployment rate. In contrast, growing financial payments in 1997-2001 and 2005-2009 account, respectively, for 1.5 and 2.6 extra unemployment rate points.

A second key finding is that financial payments has not always been the driving force of capital accumulation and, consequently, has not always driven the impact of capital accumulation on unemployment. In 1997-2001 and 2001-2005, financial payments exert an opposite influence with variations in capital accumulation contributing to reduce unemployment by 2.5 points in the first of these periods, and to augment it by 2.2 points in the second one. However, when both variables have pushed in the same direction, we find financial payments to explain between $75 \%$ and $80 \%$ of the effects of capital accumulation on unemployment.

A third major finding relates to the identification of a structural change that clearly separates two periods regarding the relevance of financial payments. One period corresponds to years 1960-1981 in which financial payments are relatively low and scarcely volatile. In contrast, the second one, for years 1982-2009, is characterized by high financial payments and a much large volatility of this variable. When evaluating the unemployment incidence of the post-1980 financialization pattern, we find it accounts for around 2 additional structural percentage points of unemployment. This prevents the unemployment troughs of 1989 and 2000 to reach the full-employment levels reached at the end of the 1960s.

The fact that financialization crowds out productive investment and increases unemployment calls for a reappraisal of the way financial markets work and are interconnected with the product and labor markets. Policy makers should try to regain control over the massive financial flows and examine the growing orientation of non-financial firms to

\footnotetext{
${ }^{3}$ Structural vector autoregressions (SVARs) impose an economic structure in the error terms by the use of theoretical restrictions. These restrictions are not necessary in a CRT framework, whose plausibility also relies in the economic interpretation of the individual equations. CRT models, however, deal with endogeneity issues by the use of instruments, while SVAR models assume, ex-ante, that all variables are endogenous.
} 
financial imperatives (Krippner 2011). Only the integration of non-financial firms' actions and financial markets dynamics guarantees a full understanding of the post-1980 macroeconomic environment, and provides wider lens to understand the roots of the recent financial bubble and subsequent Great Recession. Of course, this complex task is far from resolved and the role of financial sector is currently object of hot debate. Our contribution to this debate is easy to summarize. Whatever the new regulations and the new financial setup emerging from this crisis are, the reorientation of the scope of financial institutions is a must. There is, in particular, an imperious need of avoiding these institutions to support financial mechanisms that go beyond the efficient provision of funding and result in productive investment crowding-out.

The plan of the paper is as follows. Section 2 describes the analytical framework in which we conduct our analysis. Section 3 deals with its empirical implementation. In Section 4 we evaluate the impact of the financialization burden in terms of lower capital accumulation and higher unemployment. Section 5 concludes.

\section{Financialization, capital accumulation and unem- ployment}

\subsection{Financialization}

Financialization is a complex concept. Broadly speaking, it refers to the growing dominance of finance in the modern economy. In line with the complexity of the phenomenon, the literature has not given a precise definition. Financialization has been used to characterize different but interconnected phenomena such as the rise of financial investment relative to real investment (Crotty 2005, Duménil and Levy 2004, Krippner 2005), the increased activity of non-financial businesses on financial markets (Stockhammer 2004a), the changing structure of corporate governance (Lazonick and O'Sullivan 2000) or the growing financial payout ratios in the form of interest payments, dividend payments and stock buybacks (Aglietta and Bretton 2001). For the purpose of this study, we follow Orhangazi (2008) and use financialization "to designate the changes that have taken place in the relationship between the non financial corporate sector and financial markets" (Orhangazi 2008, p. 864).

Beginning in the 1980s and consolidating during the 1990s, corporate strategies have dramatically changed. In parallel to the disproportionate growth of the financial sector, non-financial corporations in the U.S. started in the early 1980s to be more and more involved in investment in financial assets. A growing share of their income has since then been obtained in financial markets which, at the same time, have increased their pressure on the non-financial corporate sector resulting in increasing financial payout ratios in the 
form of interest payments, dividend payments, and stock buybacks. This has been in part due to changes in the corporate governance structure, first in response to the hostile takeover movement of the 1980s and then by proceeding to the so-called shareholder revolution of the 1990s (Krippner 2011). This is not the place to analyze the political context and the concrete financial deregulation measures that were taken in the early 1980s and did possible the explosion of financial markets. A quick glance at Figure 2 is enough to see that the early 1980 s meant a structural change in the pattern of financialization. ${ }^{4}$ Figure 2a shows the evolution of financial payments (net dividends plus net interests) made by the non-financial corporate sector as a percentage of their before-tax profits. Time series analysis (reported in section 4.2) identifies a clear structural change in 1982 in the time-path of this financialization indicator, and provides the basis to conduct a separate analysis for the permanent unemployment effects of what we call "the post-1980 pattern of financialization" (section 4.2). Figure 2b shows the non-financial corporations' ratio of financial assets to tangible assets for the period 1960-2009. Again, the early 1980s represent a break in the trend of this series. It seems reasonable to suppose that financial deregulation undertaken in the early 1980s meant the beginning of a new pattern of financialization of the non-financial corporate sector. As Krugman stated referring to the financial deregulation, "Reagan did it". 5

Figure 2. Expressions of the financialization process.

a. Financial payments

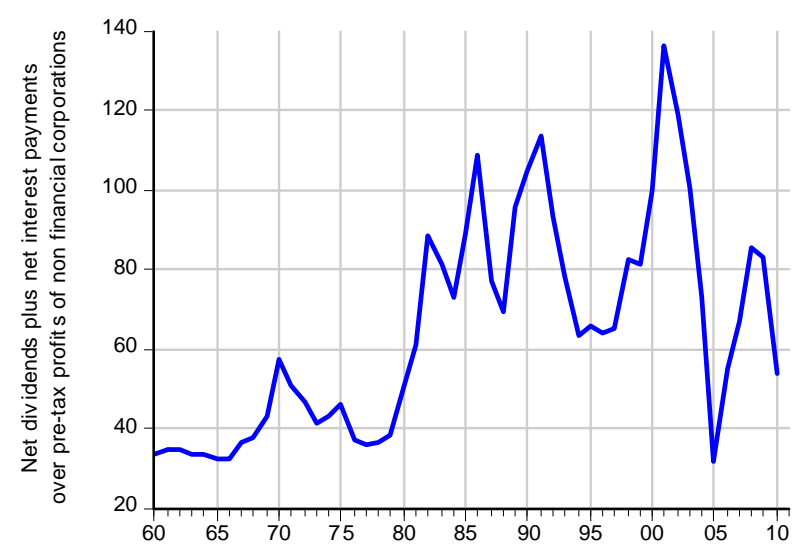

b. Financial assets

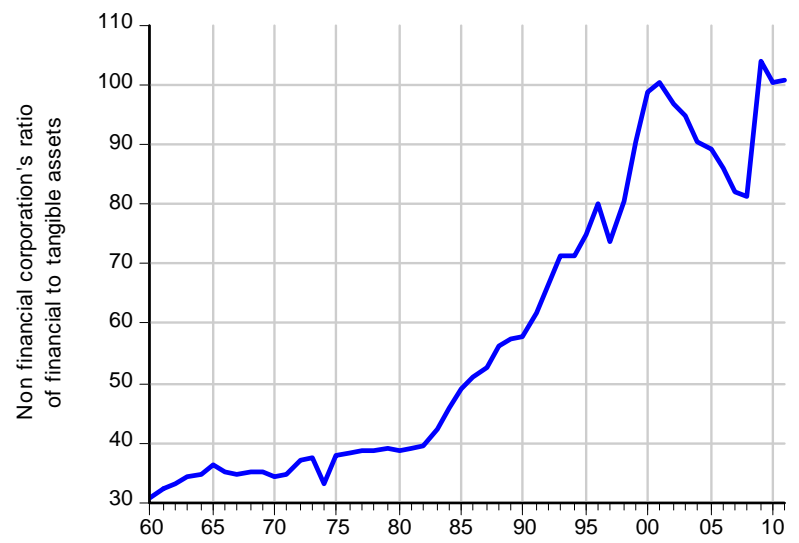

Financialization and investment - or capital accumulation- are intricately related. Two are the main channels by which financialization may have negative effects on capital accumulation (Orhangazi 2008):

- First, increasing financial investments carried out by the non-financial corporate sector may have a negative impact by crowding real investment. In other words, non-

\footnotetext{
${ }^{4}$ Krippner (2005) shows the historical time series of different financialization indicators, all of them showing a structural change in the early 1980s.

${ }^{5}$ Krugman, P. 2009. "Reagan did it", The New York Times, 31 May.
} 
financial corporations would give priority to financial investment over non-financial investment, opting for short-term financial gains over long-term growth objectives.

- Second, increased payments to financial markets -in the form of dividend and interest payments, and stock buybacks- would deplete internal funds and diminish the rate of capital accumulation.

The first channel was identified by Tobin (1956) much before the development of the literature on financialization, and even before the change of regime that the early 1980s represented. Tobin noted that financial and real investment could be potential substitutes. If financial markets offer higher returns than real investment, more funds will be invested in financial assets, and accumulation of physical capital will decline. Crotty (2005) explains the financialization process in a similar way. Starting in the 1980s and in the presence of low returns in real investment, non-financial corporations increased the search for short-run rates of returns in financial markets. Real investment crowding out would be a consequence of this short-termism. Stockhammer (2004) puts the emphasis on the change in corporate governance priorities and incentives. Non-financial corporations management started acting more like financial market investors, reflecting, again, a preference for short-term returns rather than for long-term projects. The new active role of non-financial corporations in financial markets, giving priority to financial investment over real investment, was a source of decline in capital accumulation rates. This preference for financial investment over real assets is shown in the post-1980 fast increase of the non-financial corporations' ratio of financial assets to tangible assets (Figure 2a).

The second channel refers to the passive role of the firms within financial markets. Financialization "has been characterized by increased financial payout ratios in the form of interest payments, dividend payments and stock buybacks" (Orhangazi 2008). Figure 1 shows clearly that the post-1980 average of financial payments is well above that of pre-1980 average. For Lazonick and O'Sullivan (2000), this phenomenon represents a strategy shift from "retain and reinvest" to "downsize and distribute". Increased financial payments in the forms of interests and dividends diminish the capital accumulation rate by reducing retained profits available for real investment and by limiting the access to external funds for investment purposes (own funds are an indicator for creditworthiness in incomplete financial markets). This strategy shift is the result of institutional changes such as the rise of institutional investors and the hostile takeover movement in the 1980s that resulted in the alignment of the interests of managers with those of shareholders and forced non-financial corporations to prioritize the shareholder value. In order to satisfy shareholders preferences and protect themselves from takeover threats, corporations were forced to keep a minimum return on equity, distributing higher dividends or buying back 
their own stocks (Orhangazi 2008). ${ }^{6}$ The emergence of institutional investors and their competitive character also forced non-financial corporations to look for short-term capital gains, discouraging long-term investment projects. ${ }^{7}$

Financialization of non-financial firms has also implied an unnecessary cost of autonomy (Crotty, 1990; Boyer 2000). Even though financialization has eased the access to financial markets -making investment easier-, it has also made more expensive to raise capital from financial markets - making investment more expensive-, because the return that they have to provide to financial investors in terms of financial payments has increased. Furthermore, added constraints may arise from increased indebtedness (Duménil and Levy 2004). If the result of increasing financial payouts is that firms, after transferring earnings, have to borrow to finance real investment, financialization will also entail increased corporations' indebtedness. Higher indebtedness then appears as an additional indirect effect of increased financial payments and justifies the inclusion of interest rates in financialization indicators. This substitution between equity and indebtedness has been remarked recently by Jermann and Quadrini (2012) who model the (in)ability to borrow as a source of macroeconomic shocks.

Overall, the financialization process is a complex phenomenon that may be captured through different indicators. For example, financial payments and financial incomes could be considered separately in a context in which these specific channels of transmission are the chosen ones to be studied (as in Orhangazi, 2008). Ours, however, is an aggregate study in which the focus is not on the flows of cross-firms' payments, but rather on the net payments of the corporate sector to the rest of the economy. Furthermore, when financial payments and incomes have been considered separately in an aggregate context, as in Stockhammer (2004a), they are found highly correlated and crowding out each other. Our indicator of financialization, in contrast, neatly captures the two channels of transmission of net finance payments previously discussed. ${ }^{8}$

The proposition that financialization deteriorates capital accumulation has found empirical support in recent studies. At a macro level, Van Treeck (2008) shows that increasing profit and rentier income shares have caused financing constraints and harmed accumulation during the past decades in the U.S. In turn, Stockhammer (2004a) finds a

\footnotetext{
${ }^{6}$ Stock buybacks "have now become a systematic feature of the way in which they -non-financial corporations- allocate revenues and a critically important one in terms of the money involved (Lazonick and O'Sullivan, 2000, p.23).

${ }^{7}$ The literature on institutional investors has noted that institutional investors tend to undervalue firms with good long-term earnings prospects but low current profitability (Davis and Steil, 2001, pp. 323-5, quoted by Orhangazi 2008).

${ }^{8}$ We acknowledge that net repurchases is also an important mechanism of transferring funds to the financial markets. However, we dismissed the possibility of augmenting our indicator with net repurchases to avoid blurring the picture obtained with our neat indicator of net financial payments in a context in which its augmented version greatly enhances its volatility and distorts the empirical analysis conducted in Section 4.
} 
significant negative relationship between the financialization process of the non-financial corporate sector and investment in the U.S. and France. Orhangazi (2008) explores two dimensions of financialization -increased financial investment and increased financial profit opportunities- and confirms a negative and significant relationship between financialization and real investment using firm data for the U.S. for years 1973-2003. Our analysis adds new supportive evidence, this time by focusing on the labor impact of the financialization process through the erosion in capital accumulation that stems from net aggregate financial payments made by the non-financial sector.

\subsection{Capital accumulation and unemployment}

The macro-labor literature has been largely influenced by the NAIRU model. Mainstream accounts of the unemployment problem deny the influence of capital accumulation and consider labor market institutions as the key determinant of structural unemployment: "broad movements in unemployment across the OECD can be explained by shifts in labor market institutions" (Nickell et al. 2005, p.1). ${ }^{9}$

A critical aspect of standard formulations of NAIRU models is their exclusion of growing variables such as capital stock and working age population. Mainstream literature has explained this phenomenon through what Karanassou and Snower (2004) call the "unemployment invariance hypothesis". According to this hypothesis, the labor market is able by itself to ensure that the long-run unemployment rate is independent of the size of growing variables such as capital stock, total factor productivity, and the labor force. The standard way of achieving this result is to specify a wage setting behavior so as to ensure that the wage-setting curve shifts inwards by the same amount as the labor demand curve shifts outwards.

The literature has done fundamental critiques to the "unemployment invariance hypothesis". On one side, some authors have argued that the long-run unemployment rate can be influenced by capital stock, productivity and the labor force in trendless combinations. For instance, given that the ratio of capital to labor is trendless, then the long run unemployment rate may depend on this ratio. This is called the weak invariance hypothesis in Karanassou and Snower (2004) and finds support in Phelps (1994, Ch. 17) and Fitoussi et al. (2000). It is also supported by Rowthorn (1999), who uses the capital/employment ratio (in efficiency units) to demonstrate that if capital stock

\footnotetext{
${ }^{9}$ The story of the NAIRU (Stockhammer 2004b), particularly in Europe, has been a story of blaming wage push factors -as sources of labor market rigidity- for persistently high unemployment. This view was -and its general postulates still are- strongly influential during the 1990s and early 2000s. The 1994 OCDE "Jobs Study" and the 2003 IMF study "Unemployment and Labor Market Institutions: Why Reforms Pay Off" blamed the design of unemployment benefits, employment protection legislation and wage collective bargaining mechanisms for persistently high unemployment in many European countries during the decade of the $90 \mathrm{~s}$, and it is well-known their catalog of policy reforms of flexibilization and labor market deregulation.
} 
does not affect the long-run unemployment rate in LNJ (1991), it is only because they assume a Cobb-Douglas production function -which implies that the elasticity of substitution between capital and labor is unity-. However the elasticity of substitution between capital and employment is substantially below unity (Rowthorn 1999, p. 417), so that if a constant elasticity of substitution production function (CES) is used with elasticity below unity, the capital/employment ratio affects long-run unemployment, and the weak invariance hypothesis holds.

Rowthorn (1995) develops an alternative model based on the concept of aspiration gap, which is affected by capital stock. In this model, "unemployment reduces the ability of workers to push up wages, while the excess of capacity limits the ability of firms to raise prices" (Rowthorn, 1995, p.28). Since capital accumulation increases the excess of capacity, it squeezes the firms' power to raise prices and reduces the conflict over income distribution between firms and workers. This model has been used to evaluate the impact of capital accumulation on employment (Rowthorn 1995) and on the NAIRU (Arestis and Biefang-Frisancho Mariscal 2000; Arestis et al. 2007), reporting significant effects of capital accumulation. Stockhammer (2004a, 2004b) uses a time series analysis for five countries controlling for several labor market variables, and finds strong effects of capital accumulation on unemployment. Using the Chain Reaction methodology, Karanassou et al. (2008) and Karanassou and Sala (2010a) find significant effects of capital accumulation on unemployment in the Nordic countries and Australia respectively. Empirical evidence is therefore contrary to the "unemployment invariance hypothesis" in any of its forms.

\subsection{Considering a joint framework}

Given the literature on the relationship between financialization and capital accumulation, on one side, and between capital accumulation and unemployment, on the other, we next consider a joint framework to examine the impact of financialization on unemployment. For that purpose, we take as reference a standard multi-equation labor market model, and endogenize capital formation by adding a capital accumulation equation.

Our approach is based on the Chain Reaction Theory (hereafter CRT). Analytical models of the CRT usually consist on a system of labor demand, wage- setting and labor supply equations. Along the lines of Karanassou et al. (2008), let us consider the following 
stylized model labor market model ${ }^{10}$

$$
\begin{aligned}
n_{t} & =\alpha_{1} n_{t-1}+\beta_{1} k_{t}-\gamma_{1} w_{t} \\
l_{t} & =\alpha_{2} l_{t-1}+\beta_{2} z_{t} \\
w_{t} & =\beta_{3} p r_{t}+\gamma_{3} u_{t},
\end{aligned}
$$

where $n$ is employment, $l$ is the labor force, $w$ is the real wage, $k$ is real capital stock, $z$ is working age population, $p r$ is labor productivity, and $u$ is the unemployment rate. The $\beta$ 's and the $\gamma$ 's are positive constants. The autoregressive parameters, $\alpha_{1}$ and $\alpha_{2}$, are positive and less than unity, and capture the employment and labor force adjustment costs. Wage/price staggering effects, and constant and error terms are ignored for ease of exposition. All variables are in logs and capital stock, real wages, productivity, and working-age population are assumed to be growing variables with growth rates that stabilize in the long-run. Because $l$ and $n$ are in logs, the unemployment rate $u$ can be approximated by

$$
u_{t} \simeq l_{t}-n_{t} .
$$

Equation (4) implies that the unemployment rate stabilizes in the long run, i.e. $\Delta u^{L R}=0$, when

$$
\Delta n_{t}^{L R}=\Delta l_{t}^{L R}
$$

which, as shown in Karanassou et al. (2008), can be expressed as

$$
\frac{\beta_{1}}{1-\alpha_{1}} \Delta k^{L R}-\frac{\gamma_{1} \beta_{3}}{1-\alpha_{1}} \Delta p r^{L R}=\frac{\beta_{2}}{1-\alpha_{2}} \Delta z^{L R}
$$

This shows that, contrary to single equation NRU models, dynamic multi-equation CRT models include trended exogenous variables. The only requirement for achieving dynamic stability is that each equation is balanced (i.e. dynamically stable) so that each trended dependent variable is driven by the set of its trended determinants (Karanassou et al. 2008, 2010). ${ }^{11}$ Particularly, CRT models show that capital stock influences the time

\footnotetext{
${ }^{10}$ The difference is that in Karanassou et al. (2008) the wage equation includes a wage-push factor such as benefits, rather than productivity. For the sake of brevity we just focus on the long-run stability of this sort of models containing growth drivers such as the stock of capital. Karanassou et al. (2008) show how to derive the reduced form or univariate representation of unemployment (where the term "reduced form" refers to the fact that the parameters of the univariate equation are not estimated directly but are, instead, some function of the parameters of the labor market system (1)-(3)).

${ }^{11}$ Karanassou and Snower (2004) show that the univariate representation or reduced form of actual unemployment derived from a CRT model such as the one above, is dynamically stable, even when it incorporates non-stationary explanatory variables. To see this, one should observe that the unemployment rate is obtained by the difference of two dynamically stable equations: labor supply and labor demand. labor supply is driven by working-age population (a trended variable). It is static and itself balanced. labor demand is driven by capital stock (a trended variable) and is dynamically stable since $\alpha_{1}<1$. It remains balanced once the wage has been substituted into it. The resulting univariate unemployment rate equation is dynamically stable because it is the difference between the labor supply and labor demand
} 
path of the unemployment rate, a stationary variable, challenging both the NRU models, based on the strong unemployment invariance, and other alternative models, based on the weak unemployment invariance (e.g. the unemployment rate may depend on the trendless capital/labor ratio). Karanassou and Snower (2004) show that equilibrating mechanisms in the labor market and other markets jointly act to ensure that the unemployment rate is trendless in the long run. In terms of the above stylized model, these mechanisms can be expressed by the restriction expressed in equation (5) between the long growth rate of employment (dependent on the long run growth rates of capital stock and productivity) and the long run growth rate of the labor force (dependent on the long run growth rate of working age population).

In this paper we take a step forward and go beyond the standard formulation of CRT models by endogenizing capital accumulation. This requires the addition of a fourth equation with capital accumulation as dependant variable. The crucial feature of this equation is the inclusion of an indicator of the financialization process so that we can then evaluate the unemployment impact of such process.

The theoretical discussion in section 2.1 provides the analytical basis for adding the financialization variable and expect a negative sign on its estimated coefficient. Moreover, to isolate the effect of financialization on capital accumulation, we control for other variables that affect investment decisions.

In particular, we specify a capital accumulation equation that is similar to the investment equation in Stockhammer (2004a) and that, in addition to financialization variable, incorporates the lag of capital accumulation (to capture the lag adjustment process in capital formation), capacity utilization, and the relative cost of capital:

$$
\Delta k_{t}=\alpha_{4} \Delta k_{t-1}+\beta_{4} f_{t}+\gamma_{4} c u_{t}+\delta_{4} c c_{t}
$$

where $\Delta k$ is the rate growth of capital stock (note that $k$ is in logs), $f$ is the financialization variable, $c u$ is capacity utilization, and $c c$ is cost of capital. The expected coefficient signs are $\alpha_{4}>0, \beta_{4}<0, \gamma_{4}>0$, and $\delta_{4}<0$.

We next discuss the specific variables entering the econometric specification of the model, and the empirical implementation of our analysis.

\section{Empirical implementation}

Empirically, we work with a dynamic multi-equation model containing augmented versions of equations (1), (2), (3), and (7), plus the definition equation (4). This model takes the

equations. 
following general form

$$
\mathbf{A}_{0} \mathbf{y}_{t}=\sum_{i=1}^{2} \mathbf{A}_{i} \mathbf{y}_{t-i}+\sum_{i=1}^{2} \mathbf{D}_{i} \mathbf{x}_{t-i}+\mathbf{e}_{t}
$$

where $\mathbf{y}$ is a vector of endogenous variables (employment, labor force, real wage, and capital accumulation), $\mathbf{x}$ is a vector of exogenous variables, the $\mathbf{A}_{i}$ 's and $\mathbf{D}_{i}$ 's are coefficient matrices, and $\mathbf{e}_{t}$ is a vector of identically independently distributed error terms. ${ }^{12}$

\subsection{Data and econometric methodology}

Our sample covers the 1960-2009 period. All the information is obtained from the Organization for Economic Cooperation and Development (OCDE) Economic Outlook except for the capital stock series (source: European Commission, AMECO database), the Standard \& Poor's 500 stock market index (source: Bloomberg), and net dividends, net interests and before- tax profits of non-financial corporations (source: Federal Reserve Flow of Funds Accounts database). Table 1 gives the definitions of the variables (all in logs unless otherwise indicated).

Table 1. Definitions of variables.

\begin{tabular}{ll|ll}
\hline \hline$n_{t}$ & employment & $r b_{t}$ & real balances \\
$l_{t}$ & labor supply & $f w_{t}$ & financial wealth (real S\&P's 500) \\
$u_{t}$ & unemployment rate $\left(=l_{t}-n_{t}\right)$ & $y_{t}$ & real GDP \\
$w_{t}$ & real compensation per employee & $p r_{t}^{n}$ & labor productivity $\left(=y_{t}-n_{t}\right)$ \\
$k_{t}$ & real capital stock & $p r_{t}^{k}$ & capital productivity $\left(=y_{t}-k_{t}\right)$ \\
$\Delta k_{t}$ & capital stock accumulation & $u d_{t}$ & union density (\% of employees) \\
$f p_{t}$ & financial payments & $t a x_{t}^{d}$ & direct taxes (\% of GDP) \\
& $\left(=\frac{\text { net dividends }+ \text { net interests }}{\text { total pre-tax profits of non-fin. corpors. }}\right)$ & $z_{t}$ & working-age population \\
$c$ & constant & $t$ & linear time trend \\
\hline \hline
\end{tabular}

Note: Variables are in logs unless otherwise indicated.

Sources: OECD (Economic Outlook), European Commission (Ameco database), Bloomberg, Federal Reserve (Flow of Funds Accounts of the U.S.).

Although the majority of the variables are standard in macro-labor models, some deserve more attention. Financial payments, $f p$, is our key variable as it is our indicator of financialization. It is defined as the ratio of net financial payments (net interests plus net dividends) to corporate before-tax profits. The choice of this variable is justified by

\footnotetext{
${ }^{12}$ This dynamic system is stable if all the roots of $\left|\mathbf{A}_{0}-\mathbf{A}_{1} L-\mathbf{A}_{2} L^{2}\right|=0$, where $L$ is a lag operator, lie outside the unit circle. Our estimated equations in sections 3.2 and 3.3 satisfy this condition.
} 
the need to capture the double dimension of financialization. Interests and dividends received by non-financial corporations reflect their active role in financial markets and the potential crowding out effect that result from the management preferences towards financial investments. On the contrary, interest and dividends paid by non-financial corporations reflect their passive role in financial markets: the higher financial payouts, the lower retained earnings available for real investment. ${ }^{13}$

Financial wealth, $f w$, is defined as the S\&P's stock index expressed in real terms. We include this variable following Phelps and Zoega (2001), who argue on one hand, that swings in economic activity are influenced by the firm's expectations about future productivity and the latter can be proxied by using the financial wealth variable, and on the other hand, that labor supply is conditioned by financial wealth (in a wealth effect sense).

Following Stockhammer (2004a), we use capital productivity as a proxy of capacity utilization. This affects not only the capital accumulation equation, but also the labor demand equation.

Our estimation technique is the ARDL, or bounds testing approach to cointegration analysis, developed by Pesaran and Shin (1999) and Pesaran et al. (2001). It is used in previous CRT studies (e.g. Karanassou et al. 2008, and Karanassou and Sala 2010a) because it yields consistent estimates both in the short- and in the long-run, and can be reliably used in small sample for hypothesis testing irrespective of whether the regressors are $I(1)$ or $I(0)$.

To determine the dynamic specification of each equation, we rely on the Schwarz information criterion. The selected specifications are dynamically stable and satisfy the standard diagnostics tests at conventional significance level (no serial correlation, linearity, normality and homoskedasticity). Potential endogeneity and cross equation correlation are considered, and we estimate the individual equations as a system using three-stages least squares (3SLS).

\subsection{The labor market}

Table 2 displays the 3SLS estimates of the labor market equations (the ones for the capital accumulation equation are presented in Table 3).

\footnotetext{
${ }^{13}$ Stock buybacks are not considered. Their inclusion does not significantly alter the time series of our indicator and we prefer to keep the double side (received and paid) of interests and dividends.
} 
Table 2. Estimated labor market equations. 3SLS, 1963-2009.

\section{labor demand equation}

$\begin{array}{cccccccc}c n t & n_{t-1} & w_{t} & k_{t} & p r_{t}^{k} & \Delta p r_{t}^{k} & t * 100 \\ n_{t}= & -6.21 & 0.71 & -0.47 & 0.86 & 0.44 & 0.32 & -1.46 \\ {[0.000]} & {[0.000]} & {[0.000]} & {[0.000]} & {[0.000]} & {[0.000]} & {[0.000]}\end{array}$

$R^{2}=0.999 ; S S R=0.0020 ;$ Obvs.47

$\operatorname{SC}\left[\chi^{2}(1)\right]=\underset{[0.455]}{0.56} ; \operatorname{LIN}\left[\chi^{2}(1)\right]={ }_{[0.302]}^{1.07} ; \operatorname{NOR}\left[\chi^{2}(2)\right]={ }_{[0.603]}^{1.01} ; \operatorname{HET}\left[\chi^{2}(6)\right]=\underset{[0.283]}{7.43}$

\section{labor force equation}

$\begin{array}{ccccccccc}c n t & l_{t-1} & w_{t} & \Delta w_{t} & u_{t} & z_{t} & \Delta z_{t} & f w_{t} \\ l_{t}= & -1.42 & 0.83 & -0.07 & 0.15 & -0.34 & 0.29 & 0.74 & -0.01 \\ {[0.000]} & {[0.000]} & {[0.019]} & {[0.003]} & {[0.009]} & {[0.000]} & {[0.000]} & {[0.000]}\end{array}$

$R^{2}=0.999 ; S S R=0.0002 ;$ Obvs .47

$\mathrm{SC}\left[\chi^{2}(1)\right]=\underset{[0.772]}{0.08} ; \operatorname{LIN}\left[\chi^{2}(1)\right]=\underset{[0.545]}{0.37} ; \operatorname{NOR}\left[\chi^{2}(2)\right]=\underset{[0.469]}{1.51} ; \operatorname{HET}\left[\chi^{2}(7)\right]=\underset{[0.390]}{7.38}$

\section{Wage equation}

$\begin{array}{lllllll}c n t & w_{t-1} & p r_{t}^{n} & \Delta p r_{t}^{n} & u d_{t-1} & \operatorname{tax}_{t}^{d} \\ w_{t}= & -0.14 & 0.83 & 0.17 & 0.56 & 0.09 & 0.32 \\ {[0.001]} & {[0.000]} & {[*]} & {[0.000]} & {[0.037]} & {[0.011]}\end{array}$

$R^{2}=0.997 ; S S R=0.0034 ;$ Obvs.47. $\quad H_{0}: \hat{c}\left(p r^{n}\right)=1-\hat{c}(w):$ Wald test $\left[\chi^{2}(1)\right]=0.47$

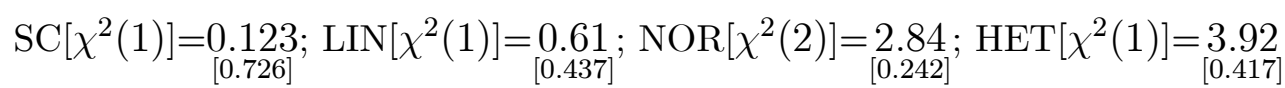

Notes: $\Delta$ denotes the difference operator; p-values in brackets.

$\left(^{*}\right)$ Restricted coefficient for a long-run unit elasticity wages/productivity: $\varepsilon_{w-p r^{n}}^{L R}=1$.

Instruments: cnt $, n_{t-1}, l_{t-1}, w_{t-1}, k_{t-1}, k_{t-2}, k_{t-3}, y_{t}, y_{t-1}, z_{t}, z_{t-1}, f w_{t}, t a x_{t}^{d}, f p_{t}, r b_{t}, r b_{t-1}, t$.

The labor demand equation is quite standard. It displays a high persistence coefficient (0.71) and shows that employment depends positively on capital stock and capital productivity (both in levels and differences), and negatively on real wages. The positive effect of capital stock is a crucial feature of our model since capital stock is the main channel through which financialization influences unemployment.

The wage setting equation is also standard. Real wages depend on its lagged value, labor productivity (in level and in differences), trade union density and direct taxes. The most remarkable feature of this equation is the unit long-run elasticity between wages and labor productivity, which cannot be rejected according to a Wald test. This elasticity results from a persistence coefficient of 0.83 and a short-run elasticity with respect to 
productivity of 0.17 so that $1=0.17 /(1-0.83)$. This implies that, in the long-run, wages grow in line with productivity. In addition, union density and direct taxes are the two institutional variables appearing as wage push factors.

Labor force depends on its lagged value, real wages (in level and in differences), unemployment, working-age population (in level and in differences) and financial wealth. As indicated by the persistence coefficient of 0.83 , labor supply decisions are more sluggish than employment decisions. Labor force depends negatively on real wage levels, but positively on their growth rate. This indicates that wealth effects dominate workers' labor supply decisions in the long-run, but not in the short-run. The negative coefficient of financial wealth confirms the hypothesis of Phelps and Zoega (2001) and is consistent with their finding of a negative impact on unemployment. The unemployment rate enters in the equation with a negative coefficient suggesting a significant discouraged worker effect (the higher the unemployment rate, the lower the incentives to participate in the labor market). On the demographic side, the labor force depends positively on working-age population.

\subsection{Capital accumulation}

Table 3 presents the system estimates of the capital accumulation equation. Two lags of the dependent variable enter the equation with an overall persistence coefficient of 0.56 $(=0.95-0.39)$. Capital productivity exerts the expected positive effect with a longrun elasticity of $0.07[=0.03 /(1-0.56)]$. If capital stock decreases, capital productivity increases and it is reasonable to expect higher capital accumulation. Relative factor prices behave as expected and growth in real wages and real balances enhance capital accumulation. Increases in the labor cost stimulate investment in capital stock since it becomes relatively less costly. The same occurs with real balances on account of the more advantageous monetary atmosphere encouraging firm's investment decisions (see Karanassou and Sala 2010b for a discussion on the relevant proxies reflecting the monetary conditions in which firms operate at the macro level).

The crucial value added of these estimates is the finding that financialization hurts investment decisions. In particular, financial payments appears as a very significant variable with a long-run elasticity that amounts to -0.23 . That is, a 1 percentage point rise in the financial payments ratio reduces the growth rate of capital by 0.23 percentage points. This is not a negligible impact in view of the wide oscillations recently witnessed in this ratio. 


$$
\begin{array}{cccccccc}
\text { cnt } & \Delta k_{t-1} & \Delta k_{t-2} & p r_{t}^{k} & \Delta w_{t} & \Delta r b_{t} & f p_{t} \\
\Delta k_{t}= & -0.66 & 0.95 & -0.39 & 0.03 & 0.15 & 0.03 & -0.10 \\
{[0.000]} & {[0.000]} & {[0.000]} & {[0.000]} & {[0.000]} & {[0.015]} & {[0.000]}
\end{array}
$$

$R^{2}=0.883 ; S S R=0.0002 ;$ Obvs .47

$\mathrm{SC}\left[\chi^{2}(1)\right]=\underset{[0.058]}{3.60} ; \operatorname{LIN}\left[\chi^{2}(1)\right]=\underset{[0.080]}{1.80} ; \operatorname{NOR}\left[\chi^{2}(2)\right]=\underset{[0.019]}{7.98} ; \operatorname{HET}\left[\chi^{2}(6)\right]=\underset{[0.099]}{10.7}$

Notes: $\Delta$ denotes the difference operator; p-values in brackets.

Instruments: cnt $, n_{t-1}, l_{t-1}, w_{t-1}, k_{t-1}, k_{t-2}, k_{t-3}, y_{t}, y_{t-1}, z_{t}, z_{t-1}, f w_{t}, t a x_{t}^{d}, f p_{t}, r b_{t}, r b_{t-1}, t$.

\subsection{System fitted values}

Figure 3 compares the fitted values resulting from the estimated system of equations with the actual trajectories of unemployment -which is the summary outcome of the labor market equations- and capital accumulation. In spite of the large amount of interactions, and thus of the numerous possibilities for the errors terms to feed in, our estimated system is able to produce a faithful replication of reality. It is on this capacity that we rely on when conducting a set of counterfactual experiments whose aim is to evaluate the financialization burden in terms of lower capital accumulation and higher unemployment rate.

Figure 3. Actual and fitted values.

a. Unemployment rate

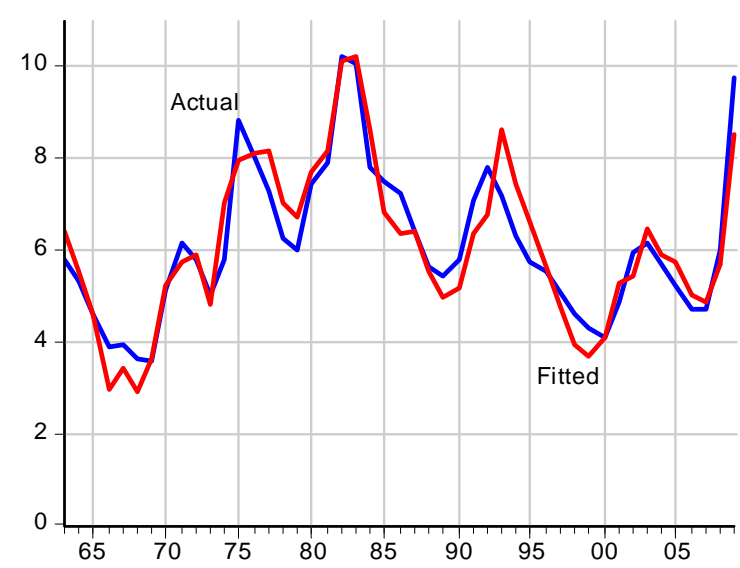

b. Capital accumulation

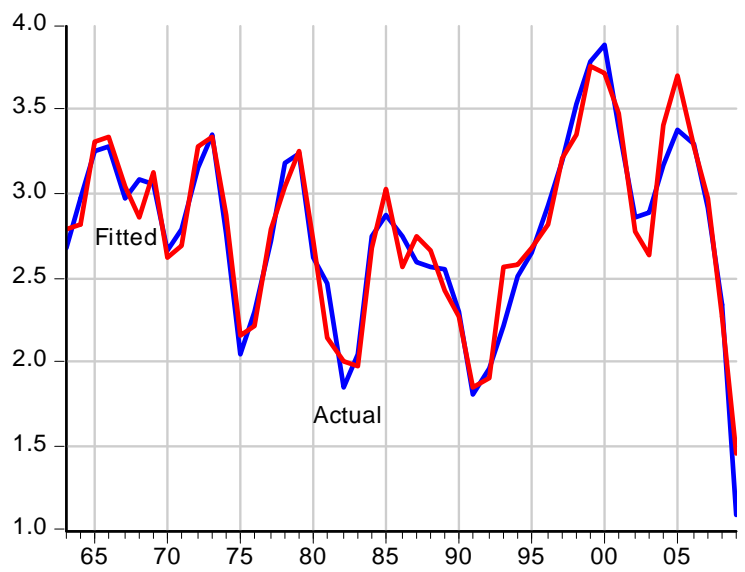

\section{The financialization burden: lower capital accumu- lation, higher unemployment}

We asses the influence of financialization on unemployment in two ways. 
In section 4.1, the contribution of financialization on unemployment is examined during four medium-term selected periods of interest corresponding, all of them, to persistent shocks in financialization (e.g., prolonged upturns or downturns in its time-path). These periods are 1991-1997, 1997-2001, 2001-2005, and 2005-2009. By means of counterfactual dynamic simulations we answer the following question: How much of the unemployment change explained by variations in capital accumulation can be attributed to changes in the dynamics of financialization?

In section 4.2, we document a structural break in the financialization series in the early 1980s giving rise to a differentiated post-1980 pattern of financialization. We examine its overall impact on unemployment and we try to give answer to the more ambitious following question: How would have unemployment evolved, from the early 1980s onwards, in the absence of the post-1980 change in the pattern of financialization?

\subsection{Contributions of financialization and capital accumulation to unemployment}

For each selected period we simulate the model -i.e. the 3SLS estimated equations presented in Tables 2 and 3, together with the unemployment definition in equation (4)under the counterfactual scenario that financialization (financial payments) is fixed at its value at the beginning of that period. Figures 4a, 5a, 6a and 7a plot the actual series of financial payments and their fixed values in 1991-1997, 1997-2001, 2001-2005 and 20052009. In turn, Figures 4b, 5b, $6 \mathrm{~b}$ and $7 \mathrm{~b}$ plot the trajectories of actual unemployment and the simulated unemployment rate when financial payments are kept constant, respectively, at their 1991, 1997, 2001 and 2005 values. In other words, in figures "a" we show the shocks (or impulses), while in figures "b" we show the responses.

Through these simulations we can evaluate how the unemployment trajectory would have evolved had financial payments remained at the initial value of the correspondent period. The dynamic contribution of financial payments to the evolution of unemployment (note that this is the title of Figures 4 to 7 ) is then measured as the difference between the simulated trajectories and the actual trajectory of unemployment.

Financialization enters in the model as one of the driving forces of capital accumulation, but it is not the only one. Thus, to contextualize the unemployment effects of financialization, it is convenient to compare them with the unemployment effects of capital accumulation as a whole. For this purpose, we also simulate the dynamic contributions of capital accumulation to the evolution of unemployment.

In this second exercise, capital accumulation is treated as an exogenous variable and only the labor market equations are used in the simulation. Figures 4c, 5c, 6c and 7c plot the actual series of capital accumulation and their fixed values over the same periods 
considered before. In turn, Figures $4 \mathrm{~d}, 5 \mathrm{~d}, 6 \mathrm{~d}$ and $7 \mathrm{~d}$ plot the trajectories of the actual and simulated unemployment rate (the latter when capital accumulation is kept constant at the beginning of each period).

In this way our analysis yields a variety of new insights. First of all, a quantification of the financialization burden in terms of unemployment. Second, a quantification of the impact of capital accumulation on unemployment irrespective of the driving forces behind the accumulation of capital (note that these results are directly comparable with the ones obtained by Karanassou et al., 2008, for the Nordic countries and Karanassou and Sala, 2010, for Australia using also the CRT methodology). Third, by comparing both results -the ones shown in Figures 4b-7b against the ones in Figures 4d-7d- we gain a better understanding of how financialization influences the evolution of capital accumulation.

Our first period of analysis is 1991-1997, when the unemployment rate decreased by 2 percentage points (pp hereafter), falling from $7.1 \%$ in 1991 to $5.1 \%$ in 1997 . As the actual trajectories of figures $4 \mathrm{a}$ and $4 \mathrm{c}$ show, it was a period of strong pace in capital accumulation and rapid decline in financialization.

The results for this period are pictured in Figure 4. They show that financialization was a strong driving force of both capital accumulation and unemployment during these years. In particular, in the absence of the downward trend in financial payments, the unemployment rate would have reached $10 \%$ in 1997 (Figure 4b). Figure 4d displays the trajectory that the unemployment rate would have had if capital accumulation had kept constant at its 1991 levels. In absence of the uptrend of capital accumulation, unemployment would have reached $11.5 \%$ in 1997 (Figure 4d). The small difference of 1.5pp between the simulated trajectories in Figures $4 \mathrm{~d}$ and $4 \mathrm{~b}$ suggest that financialization was the main driving force of capital accumulation and unemployment.

Years 1997-2001 are characterized by a strong rise of financial payments, an initial rising capital accumulation rate, until 2000, and a later decline. This period was characterized by the dot-com bubble, covering roughly 1995-2000 with a climax on March 10 2000, when the NASDAQ peaked at 5132.52. During these years, stock markets in the U.S. (and other industrialized nations) saw their equity value grow rapidly along the rise in the Internet sector and associated industries.

In the absence of this upward trend in financialization, the unemployment rate would have been much lower, reaching $3.4 \%$ instead of $4.9 \%$, as shown in Figure 5b. This implies that the rise in financial payments during these years account for $1.5 \mathrm{pp}$ of unemployment. Regarding capital accumulation, Figure 5c shows its acceleration in 1997-2000, and a sudden fall in 2001 in which it nevertheless grew at $3.4 \%$. In the absence of such expansionary behavior, the rate of unemployment would have reached $7.4 \%$, that is, 2.5 pp more than it actually did. This is the contribution of capital accumulation to the labor market performance in spite of the growing financial payments. 
Figure 4. Dynamic contributions to unemployment in 1991-1997.

a. Financial payments

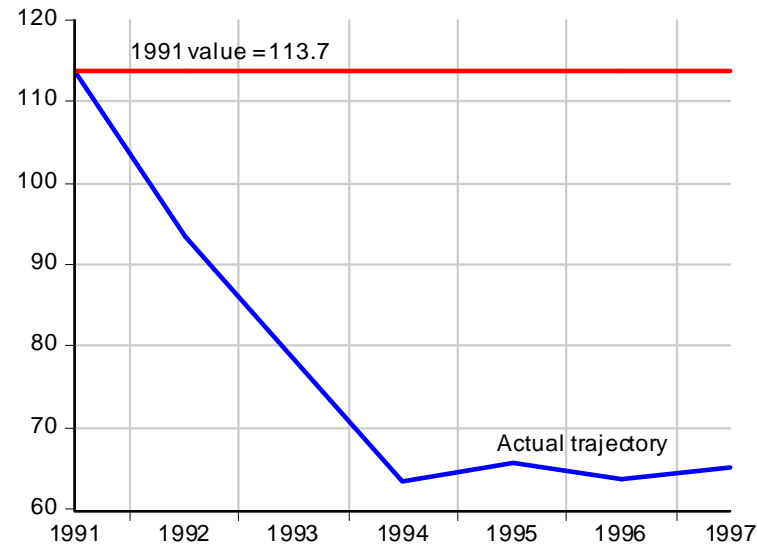

c. Capital accumulation

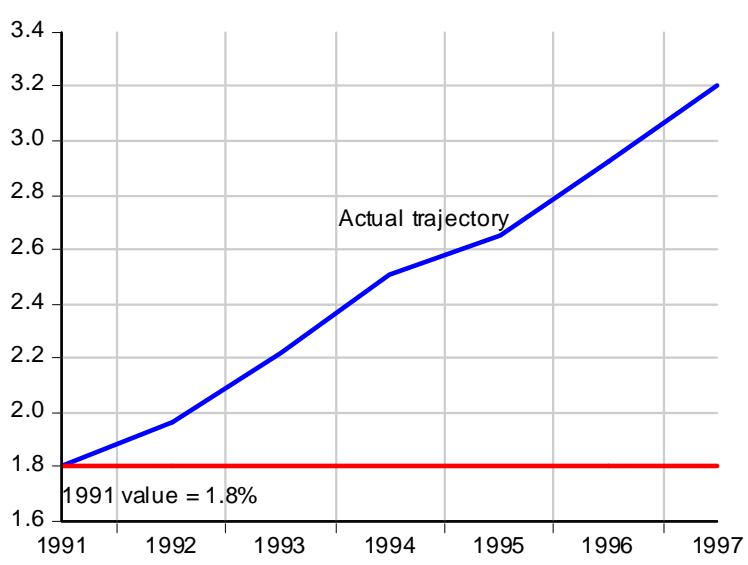

b. Contributions of financial payments

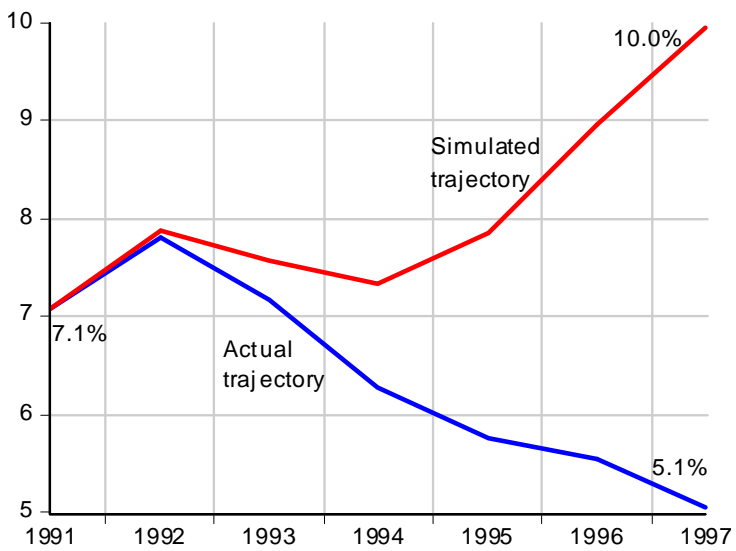

d. Contributions of capital accumulation

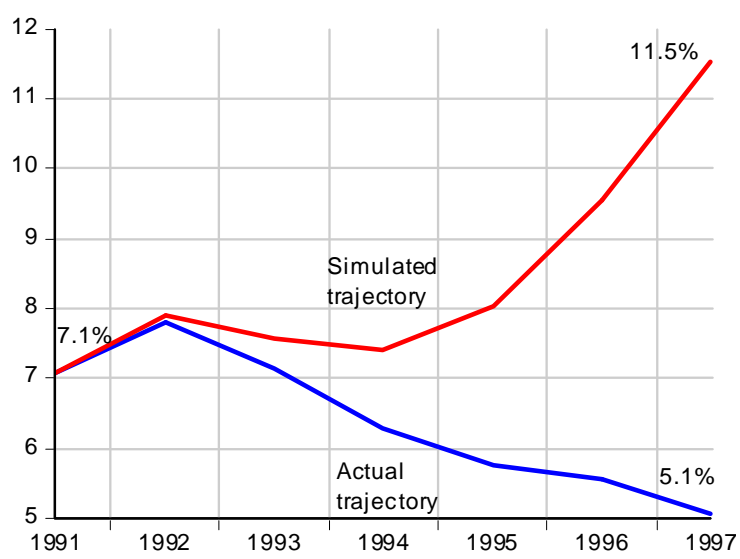

These results imply that financialization was not the key driving force of capital accumulation during those years and picture a situation consistent with the existence of a stock market bubble where higher financial payments coincide in time with higher capital accumulation.

Years 2001-2005 are characterized by a sharp decline in financial payments, from 140\% in 2001 to less than $40 \%$ in 2005, consistent with the crash of the dot-com bubble. The unemployment rate hardly changed during this period and just evolved from $4.9 \%$ in 2001 to $5.2 \%$ in 2005 .

Figure $6 \mathrm{~b}$ documents notable effects of the sharp decline in financial payments with a contribution of $2.5 \mathrm{pp}$ of unemployment. In other words, had financial payments maintained their top 2001 value, the unemployment rate would have reached $7.7 \%$. This is a substantial impact once again. On its side, capital accumulation decelerates again in 2002 and stays below a rate of $3 \%$ still in 2003. There is some recovery in 2004-2005, but the growth rate of capital stock still evolves below its departing value. This hurts unemployment which could have reached a rate of $3 \%$ in 2005 had capital accumulation evolved, instead, at its 2001 growth rate of 3.4\%. 
Figure 5. Dynamic contributions to unemployment in 1997-2001.

a. Financial payments

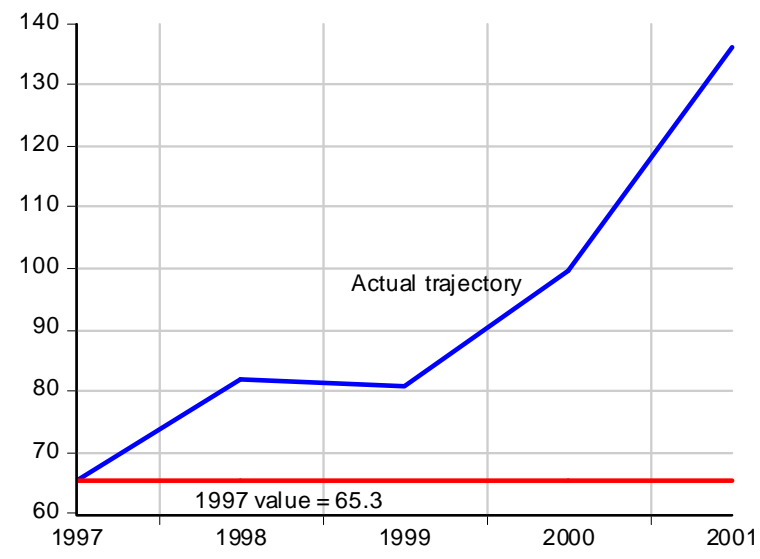

c. Capital accumulation

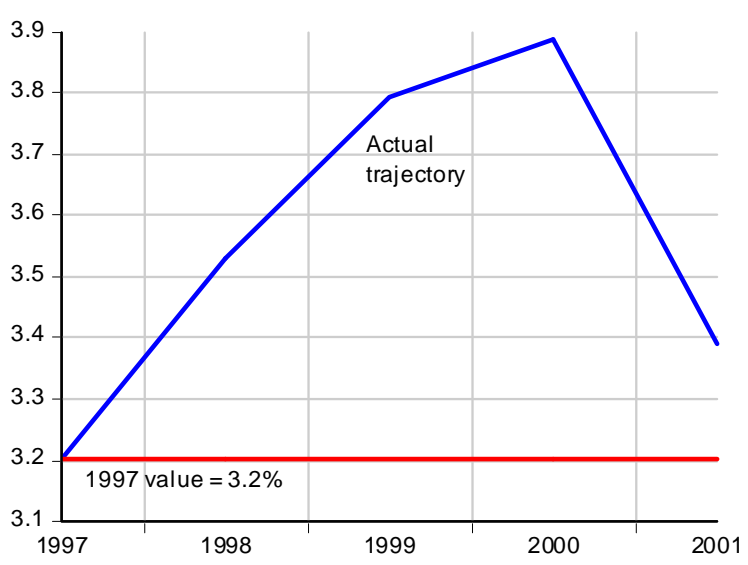

b. Contribution of financial payments

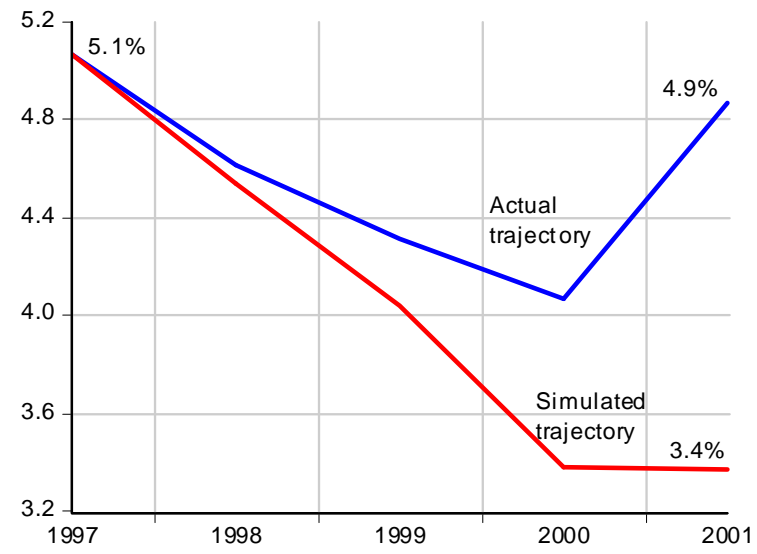

d. Contribution of capital acc umulation

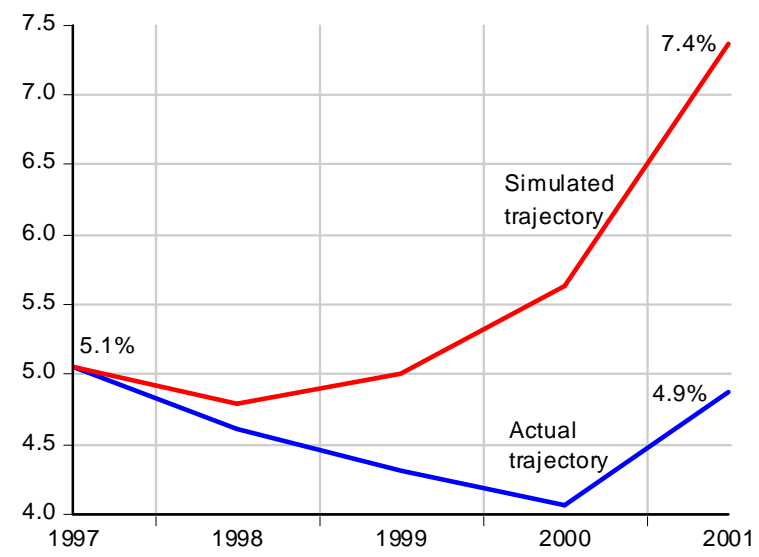

The story told by this exercise is thus subtle. Both capital accumulation and financialization fell (or remained at low levels) in the aftermath of the dot-com crash. This gave rise to two countervailing forces, one that accounts for $2.5 \mathrm{pp}$ of unemployment that were saved thanks to the lower financial payments and the resulting boost in capital accumulation; and another one that accounts for a $2.2 \mathrm{pp}$. increase caused by the overall deceleration in capital accumulation. This reveals, on one hand, that financial payments were still not the key capital accumulation driver. Even if they fell, it took some time for the economy to expand investment. On the other hand, this may explain why the unemployment rate was so much stable during this business cycle, in contrast to the historically sensitive behavior that the US labor market has shown when facing recessions and expansions. 
Figure 6. Dynamic contributions to unemployment in 2001-2005.

a. Financial payments

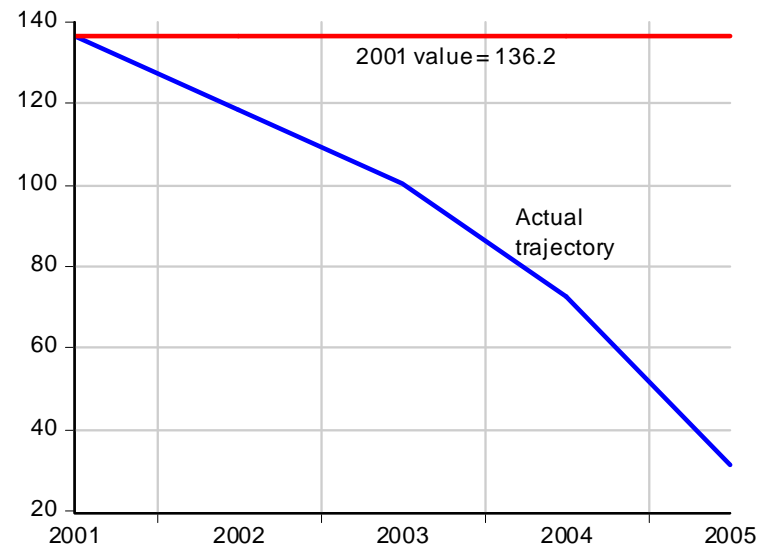

c. Capital accumulation

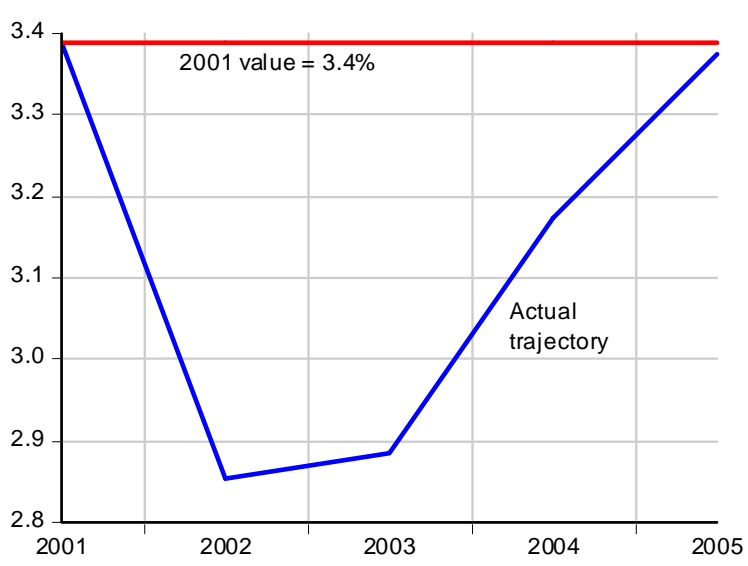

b. Contributions of financial payments

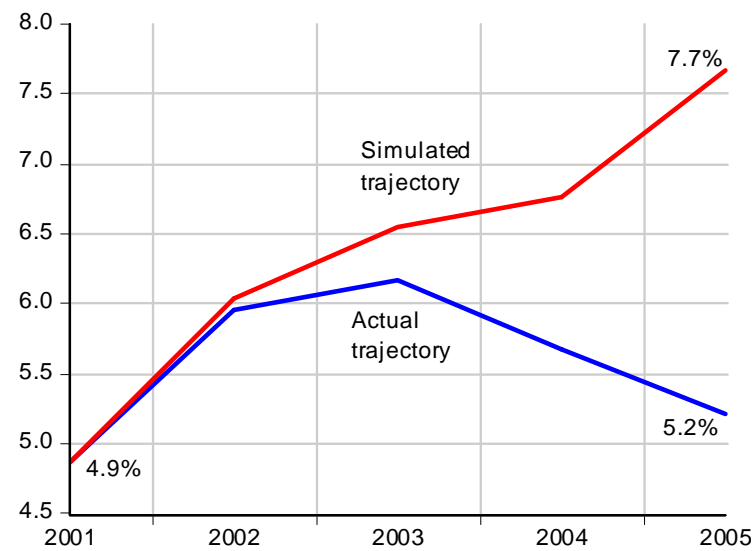

d. Contributions of capital accumulation

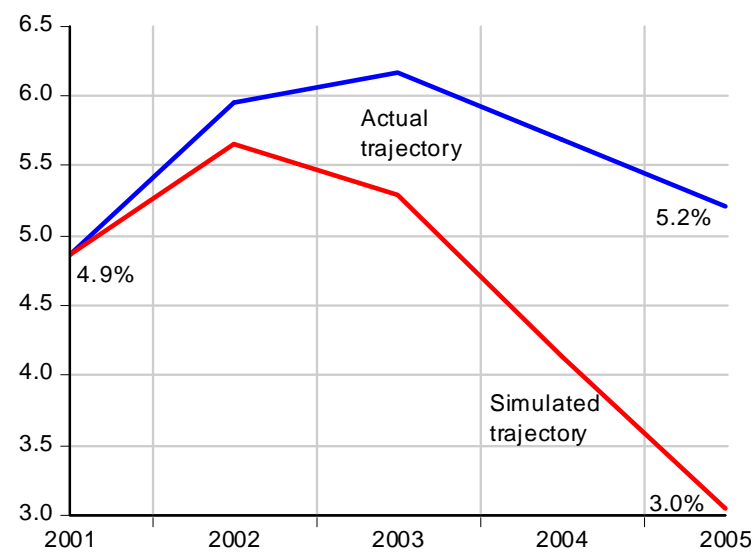

The period 2005-2009 is the prelude of the Great Recession, although the financial crisis was "officially" declared in September 2008, with the bankruptcy of Lehman Brothers. These years are characterized by a sharp rise in financial payments, which rose from $30 \%$ in 2005 to more than $100 \%$ in 2009 , and a falling growth rate of capital stock, which fell from $3.5 \%$ in 2005 to near $1 \%$ in 2009 . Both variables push in the same direction, as in 1991-1997, but this time contributing to increase unemployment.

Figure $7 \mathrm{~b}$ shows that in absence of the upward trend in financial payments, the rate of unemployment would have been $2.6 \mathrm{pp}$ lower in 2009. In turn, Figure 7 d shows that in absence of the downward trend in capital accumulation, unemployment would have been 3.3 pp lower. In other words, almost $80 \%$ of the effects of capital accumulation on unemployment can be explained by the crowding out effects of financial payments over productive investment. 
Figure 7. Dynamic contributions to unemployment in 2005-2009.

a. Financial payments

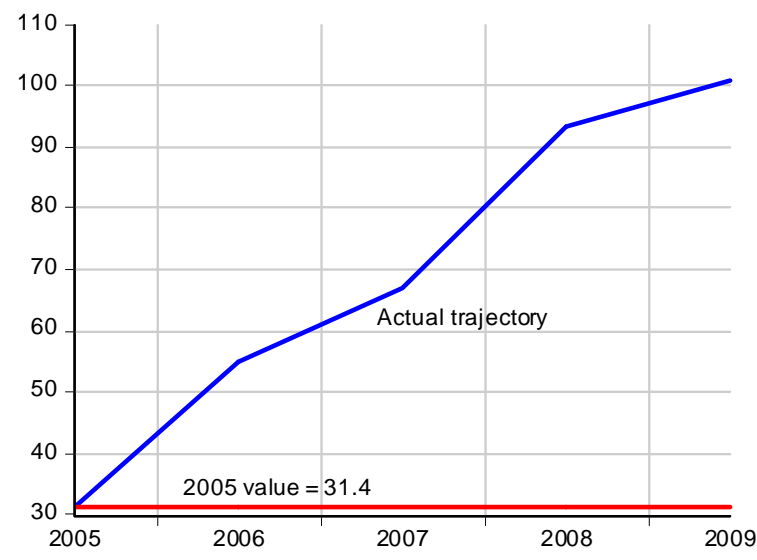

c. Capital accumulation

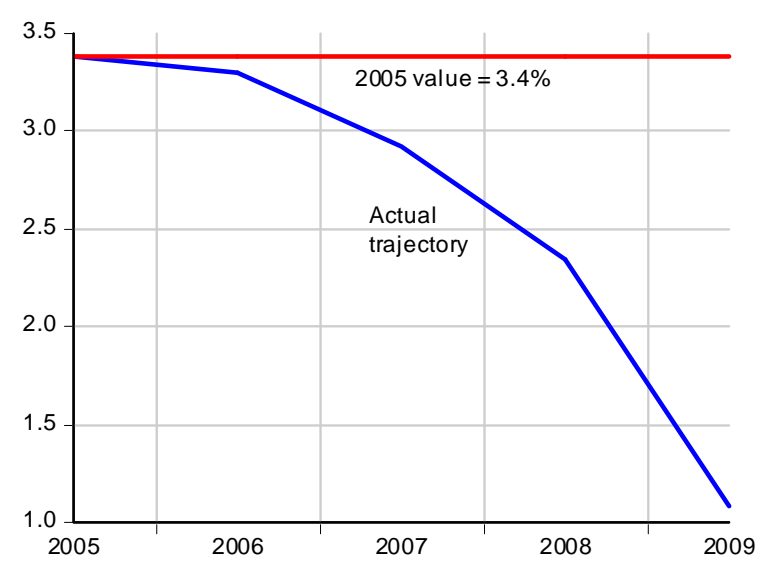

b. Contributions of financial payments

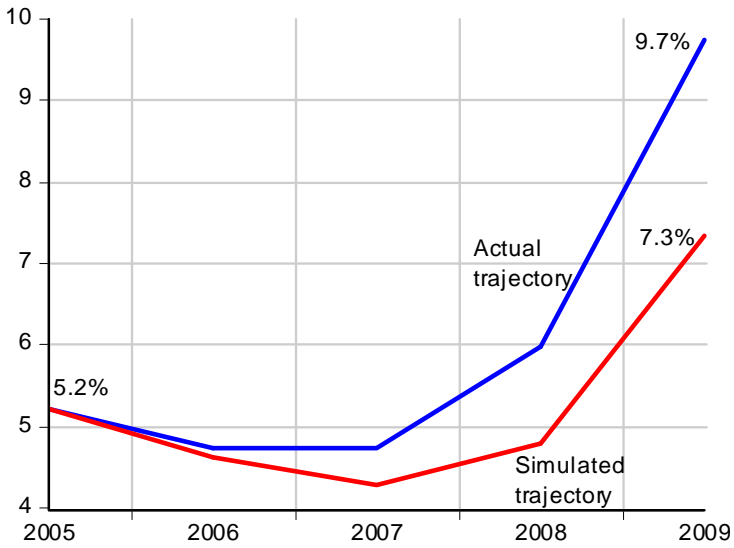

d. Contributions of capital accumulation

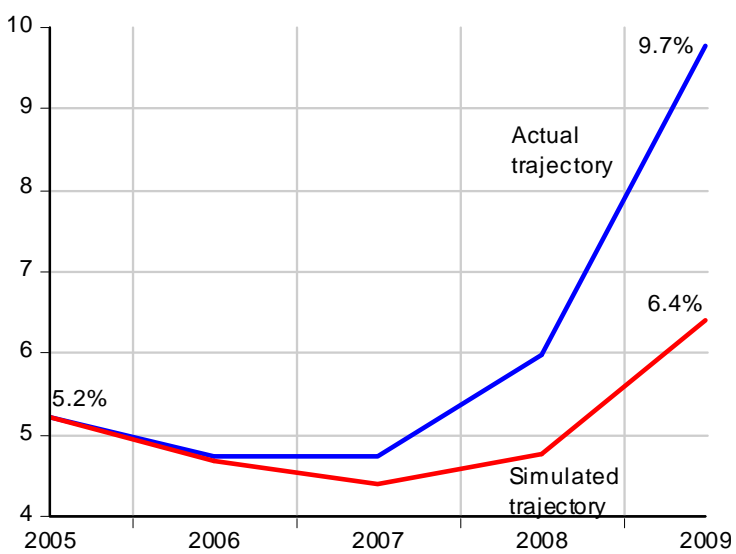

\subsection{The post-1980 pattern of financialization and its labor mar- ket impact}

It is well known that the political changes brought about by the new Republican government in the early 1980s prompted a new era of liberalization and deregulation of financial activities. During this time, regulation of banks and financial markets became less stringent. One of the most well-known Reagan Administration initiatives was the Garn-St. Germain Depository Institutions Act, enacted in 1982, whose major provisions included: elimination of deposit interest rate ceilings, elimination of the previous statutory limit on loan to value ratio, and expansion of the asset powers of federal Saving and Loans Institutions. It was not the only measure conducting to financial deregulation during the 1980s, but this is not the place to enumerate them since the phenomenon has been well documented -see, for example, Krippner (2011)-.

Figure 2 shows that one central expression of these changes was a new pattern of financialization of the non-financial corporate sector. To check whether this new pattern can be interpreted as a structural change, we have used the time series of financial payments 
to estimate an ARIMA model. Our aim is to check to what extent the possibility of a new regime of high financialization receives statistical support.

The best fit to the data generating process can be obtained from the following regression (p-values in brackets):

$$
f p_{t}=\underset{[0.015]}{14.3}+\underset{[0.000]}{1.09} f p_{t-1} \underset{[0.045]}{-0.29} f p_{t-2}, \quad R^{2}=0.731
$$

which allows us to conduct a Chow Breakpoint test. When testing the possibility of a structural change in 1982, the null of no break is rejected with an $F$-statistic of 5.01 and a probability $F(3,42)=0.005$. Moreover, when adding a dummy taking value 11982 onwards, the estimated specification is clearly improved:

$$
f p_{t}=\underset{[0.000]}{24.0}+\underset{[0.000]}{0.89} f p_{t-1} \underset{[0.001]}{-0.46} f p_{t-2}+\underset{[0.000]}{24.5 d^{82}} R^{2}=0.800
$$

We use this information to conduct a Kernel density analysis that identifies the two regimes means in financial payments corresponding to the two periods identified (for details on this type of analysis see Karanassou et al., 2008). Figure 8a shows the results of the Kernel analysis while Figure $8 \mathrm{~b}$ depicts the two estimated regime means together with the actual series.

Beyond the high and low regime means identified, it is important to remark the different shapes of the estimated Kernel density distribution functions. The one corresponding to $1960-1981$ is compact and vertical (i.e., high densities in few points) in congruence with the low volatility of financial payments in those years. In contrast, the one for years 19822009 is diffuse (i.e., low densities for many data points) and reflects the large volatility of its pattern since the 1980s.

It is also worth noting that the difference between the regime means we can be considered as a permanent shock. The ratio of financial payments over corporate profits used to oscillate around a value of 35 and has more than doubled in the post-1980 period to oscillate around 77. What has been the impact of this structural change? To answer this question we simulate the model in a steady state scenario in which (i) adjustments have taken place (that is, we simulate the model assuming it has converged, which implies that the lagged dependent terms in each equation are set at the current period); and (ii) output and capital stock grow at the same rates so that the their ratio is constant as predicted by standard growth models.

In this situation, the impact of the post-1980 pattern of financialization accounts for about two percentage points of unemployment from 1982 to 2001. This is pictured in Figure 8c and reveals an interesting feature. In the absence of this new pattern of financialization, the U.S. labor market would have been more likely to recover the fullemployment levels that characterized the U.S. (and the advanced economies) prior to the 
oil price shocks of the 1970s. Note, in particular, that the unemployment rate troughs of the 1980s and the 1990s are very close to the one reached at the end of the 1960s. In contrast, the large volatilities of financial payments in the 2000s distort the picture and impede to gain new insights beyond the ones we have already documented by simulating the persistent shocks of these years (recall that financial payments went rapidly down in the early noughties with the explosion of the dot-com bubble, the $9 / 11$, and the rising oil prices with the second Iraq war, while they experienced and unprecedented rise afterwards, along the housing and financial bubble that lead to the Great Recession).

Figure 8. Unemployment effects of the post-1980 pattern of financialization. a. Kernel density analysis

b. Financial payments
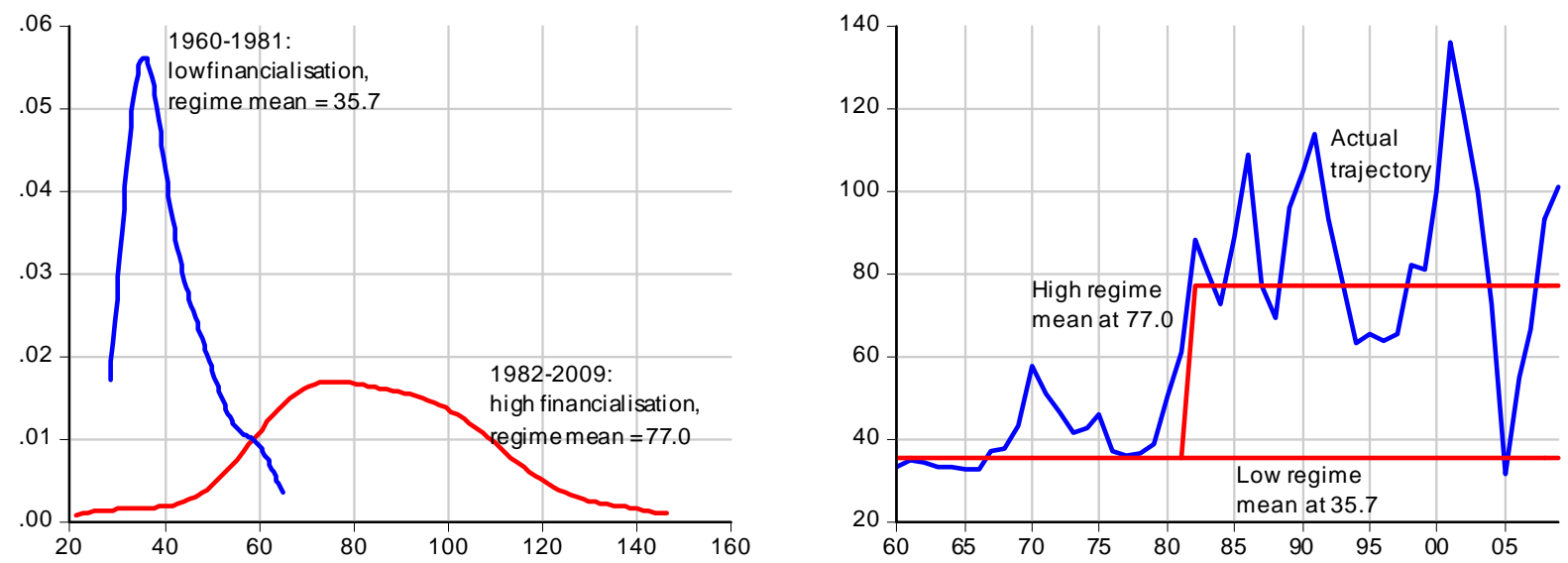

c. Unemployment effects of the regime change

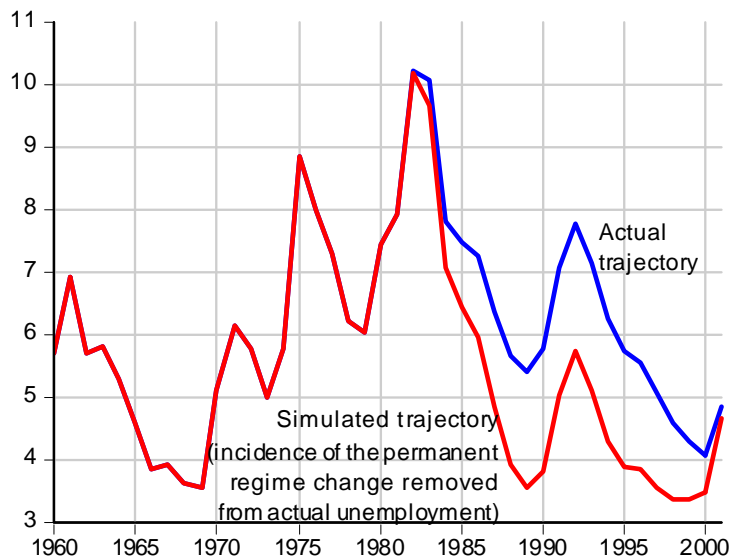

\section{Concluding remarks}

This paper follows the CRT methodology (i) to estimate a dynamic multi-equation labor market system that incorporates a capital accumulation equation; and (ii) to conduct counterfactual simulations that assess the impact of financialization on U.S. unemployment through its effect on capital accumulation. The possibility of evaluating actual 
persistent shocks is a crucial value added of the CRT methodology as compared with the VAR methodology where merely one-off shocks (generic in VARs, identified in SVARs) are generally examined. This value added stems from the feasibility of quantifying the actual impact of new or changing phenomena such as the enhanced financialization process experienced by the U.S. since the early 1980s.

In doing so, we find that financialization was a driving force of unemployment and capital accumulation during years 1991-1997 and 2005-2009. In contrast, simulations for periods 1997-2001 and 2001-2005 suggest that capital accumulation was mainly driven by other factors. We have also identified a structural change in the early 1980s in the dynamics of financialization. Our simulation suggests that in the absence of the post1980 pattern of financialization, the U.S. would have been more likely to recover the full-employment levels that characterized this economy prior to the oil price shocks of the 1970s.

We acknowledge that our findings are based on a particular indicator of a financialization process that has multiple, and not always coherent, expressions. This is the reason why these results need to be placed into a wider context allowing for a better comprehension of this phenomenon, and of its social and economic implications. However our indicator aims to explain financialization not merely as an era of easy credit and recurrent speculative bubbles, but as a phenomenon that takes place and shapes the fundamental relationship between the non financial sector and financial markets. Since a discussion on the appropriate policies to deal with all the dimensions of the financialization process is beyond the scope of this article, we focus the brief policy discussion on the recommendations that naturally arise from this relationship.

We have identified the rise in financial payments as the result of a strategy shift from "retain and reinvest" to "downsize and distribute". To invert this phenomenon, economic policy measures could aim at reforming taxation on capital gains ${ }^{14}$ and returns to capital (dividends) so as to discriminate short- and long-run gains, and put brakes on speculation. Also, if we accept that managers' interests have become excessively aligned with those of shareholders, measures limiting the use of stock options would contribute to detach the reward scheme of executives from financial markets' performance. Policies along these lines might prevent financial devices to result in productive investment crowding-out and may force financial markets to contribute efficiently to finance the real economy and generate employment.

\section{References}

[1] Aglietta, M. and R. Breton (2001) "Financial systems, corporate control and capital accu-

\footnotetext{
${ }^{14}$ Recall that capital gains are gains derived from the difference between the purchase price and the sale price of an asset.
} 
mulation", Economy and Society, 30 (4), 433-466.

[2] Arestis, P. and I. Biefang-Frisancho Mariscal (2000) "Capital stock, unemployment and wages in the UK and Germany", Scottish Journal of Political Economy, 47 (5), 487-503.

[3] Arestis, P., M. Baddeley and M. Sawyer (2007) "The Relationship Between Capital Stock, Unemployment And Wages In Nine Emu Countries", Bulletin of Economic Research, 59(2), 125-148.

[4] Baccaro, L. and D. Rei (2007) "Institutional determinants of unemployment in OECD countries: Does the deregulatory view hold water?" International Organization, 61, 527569.

[5] Baker, D., A. Glyn, D. Howell, and J. Schmitt (2005) "Labor market institutions and unemployment: a critical assessment of the cross-country evidence", in Howell, D. (ed.), Fighting Unemployment. The Limits for Free Market Orthodoxy. Oxford: Oxford University Press.

[6] Bassanini, A. and R. Duval (2006) "Employment Patterns in OECD Countries: Reassessing the Role of Policies and Institutions", OECD Economics Department Working Paper No. 486.

[7] Boyer, R. (2000) "Is a finance-led growth regime a viable alternative to Fordism? A preliminary analysis", Economy and Society, 29(1), 111-145.

[8] Crotty, J. (1990) "Owner-Manager Conflict and Financial Theory of Investment Stability: A Critical Assessment of Keynes, Tobin and Minsky", Journal of Post Keynesian Economics, 12 (4), 519-542.

[9] Crotty, J. (2002) "The Effects of Increased Product Market Competition and Changes in Financial Markets on the Performance of Nonfinancial Corporations in the Neoliberal Era", Political Economy Research Institute Working Paper No. 44.

[10] Crotty, J. (2005) "The Neoliberal Paradox: The Impact of Destructive Product Market Competition and Modern Financial Markets on Nonfinancial Corporations Performance in the Neoliberal Era", in Epstein, G. (ed.), Financialization and the World Economy, Northampton, MA: Edward Elgar.

[11] Davis, E. P. and B. Steil (2001) Institutional Investors, Cambridge, MA: The MIT Press.

[12] Duménil, G. and D. Lévy (2004) Capital Resurgent, Cambridge, MA: Harvard University Press.

[13] Fitoussi, J. P., D. Jestaz, E. S. Phelps and G. Zoega (2000) "Roots of the Recent Recoveries: Labor Reforms or Private Sector Forces?" Brookings Papers on Economic Activity 1:2000, $237-311$.

[14] Jermann, U., and V. Quadrini (2012): "Macroeconomic Effects of Financial Shocks", The American Economic Review, 102 (1), 238-271.

[15] Karanassou, M and H. Sala (2010a) "Labor Market Dynamics in Australia: What Drives Unemployment?", The Economic Record, 86(273), 185-209.

[16] Karanassou, M. and H. Sala (2010b) "The US Inflation-Unemployment Trade-off Revisited: New Evidence for Policy Making", Journal of Policy Modeling, 32 (6), 758-777.

[17] Karanassou, M., H. Sala, and D.J. Snower (2010) "Phillips Curves and Unemployment Dynamics: A Critique and a Holistic Perspective", Journal of Economic Surveys, 24 (1), 1-51. 
[18] Karanassou M., H. Sala, and P.F. Salvador (2008) "Capital Accumulation and Unemployment: New Insights on the Nordic Experience", Cambridge Journal of Economics, 32, 977-1001.

[19] Karanassou, M. and Snower, D.J. (2004), "Unemployment Invariance", German Economic Review, 5, 297-317.

[20] Krippner, G. (2005) "The financialization of the American economy", Socio-Economic Review, 3(2), 173-208.

[21] Krippner, G. (2011) , Capitalizing on Crisis. The Political Origins of the Rise of Finance, Cambridge, MA: Harvard University Press.

[22] Layard, R., S. Nickell, and R. Jackman (1991, 2005) Unemployment: Macroeconomic Performance and the Labor Market, Oxford: Oxford University Press.

[23] Lazonick, W. and M. O'Sullivan (2000) "Maximizing shareholder value: a new ideology for corporate governance", Economy and Society, 29(1), 13-35.

[24] Lowenstein, R. (2004) Origins of the Crash: The Great Bubble and Its Undoing, New York: The Penguin Press.

[25] Nickell, S., L. Nunziata, and W. Ochel (2005) "Unemployment in the OECD since the 1960s. What do we know?", Economic Journal, 115, 1-27.

[26] Orhangazi, O. (2008) "Financialization and capital accumulation in the non-financial corporate sector: A theoretical and empirical investigation on the US economy: 1973-2003", Cambridge Journal of Economics, 32, 863-886

[27] Pesaran, M.H. and Y. Shin (1999) "An Autoregressive Distributed-Lag Modelling Approach to Cointegration Analysis" in S. Strom (ed.), Econometrics and Economic Theory in the Twentieth Century: The Ragnar Frisch Centennial Symposium, Cambridge, UK: Cambridge University Press.

[28] Pesaran, M.H., Y. Shin, and R.J. Smith (2001) "Bounds testing approaches to the analysis of level relationships", Journal of Applied Econometrics, 16, 289-326.

[29] Phelps, E. and G. Zoega (2001) "Structural Booms: Productivity Expectations and Asset Valuations", Economic Policy, 32, 85-126.

[30] Rowthorn, R. (1995) "Capital formation and unemployment", Oxford Review of Economic Policy, 11(1), 26-39.

[31] Rowthorn R. (1999) "Unemployment, Wage Bargaining and Capital-Labour Substitution", Cambridge Journal of Economics, 23, 413-425.

[32] Stockhammer, E. (2004a) "Financialization and the slowdown of accumulation", Cambridge Journal of Economics, 28(5), 719-741.

[33] Stockhammer, E. (2004b) The Rise of Unemployment in Europe: a Keynesian Approach, Cheltenham, UK: Edward Elgar.

[34] Stockhammer, E. and E. Klär (2011) "Capital Accumulation, Labour Market Institutions, and Unemployment in the Medium Run", Cambridge Journal of Economics, 35, 437-457.

[35] Tobin, J. (1965) "Money and economic growth", Econometrica, 33, 671-84.

[36] Van Treeck, T. (2008): "Reconsidering the Investment-Profit Nexus in Finance-led Economies: An ARDL-based Approach", Metroeconomica, 59(3), pp. 371-404. 